\title{
MORISCOS AND ARABIC STUDIES IN EUROPE ${ }^{1}$
}

\section{MORISCOS Y ESTUDIOS ÁRABES EN EUROPA}

\author{
Gerard Wiegers \\ University of Amsterdam
}

\begin{abstract}
The essay studies the contribution of Moriscos to Arabic studies. It concludes that the contributions of Moriscos in the Iberian peninsula remained modest. Some contributed actively to the knowledge of Arabic through their Arabic-Islamic learning. I show that the Mudejar convert known as Juan Andrés, who wrote one of the most influential treatises against Islam, was indeed a canon of the cathedral of Granada. I briefly discuss the contribution of Moriscos to the translations and interpretations of the Lead Books and studied their post-expulsion contribution to Arabic and Islamic studies. The last part focuses on the Dutch Republic, where, as a result of historical circumstances and contingent factors such as personal relations, Moriscos played an important role. Here, in addition to the study of the Arabic language itself, the physical sciences played a noteworthy role. This, I suggest, can be connected to the broad scope of the emergence of Arabic studies in Europe, which incorporated both the physical sciences and religion and philosophy, and an interest in North Africa itself because of developments in the physical sciences, including their application in daily life.
\end{abstract}

Keywords: Mudejars; Moriscos; Conversos; Arabic Studies; Natural Sciences; Morocco; Contacts between Islam and the West; Religious Texts; Magical Texts.
Este artículo analiza la aportación de los moriscos a los estudios árabes, concluyendo que ésta fue modesta en la Península Ibérica. Algunos moriscos contribuyeron de forma activa al conocimiento del árabe a través de sus estudios sobre temas árabo-islámicos. Se demuestra que el converso mudéjar conocido como Juan Andrés, autor de uno de los más influyentes tratados contra el Islam, fue un canónigo de la Catedral de Granada. Se aborda brevemente la cuestión de la contribución de los moriscos a la traducción e interpretación de los Libros Plúmbeos y se estudia su contribución, con posterioridad a la expulsión, a los estudios árabes e islámicos. La última parte del trabajo se centra en Holanda (República de los Siete Países Bajos Unidos) donde, como resultado de circunstancias históricas y ciertas contingencias como las relaciones personales, los moriscos desarrollaron un importante papel. En este caso, además del estudio de la lengua árabe en sí mismo, las ciencias físicas cobraron una notable importancia, circunstancia relacionada, en un marco más amplio, con la emergencia de los estudios árabes en Europa, que incorporan tanto las ciencias físicas como la religión y la filosofía, además del interés por el Norte de África, incluidas sus aplicaciones en la vida diaria.

Palabras clave: Mudéjares; moriscos; conversos; estudios árabes; ciencias naturales; Marruecos; relaciones islam-oeste; textos religiosos; textos mágicos.

${ }^{1}$ I gratefully acknowledge the help of Juan Sánchez Ocaña, archivist at the Sacromonte Abbey, who gave me access to the riches of the archive during research there in May 2010. 


\section{Introduction}

In his thesis on Arabic studies in the Renaissance Robert Jones argues that circumstances in the Iberian peninsula did not play a major part in the development of Arabic studies in the late sixteenth and early seventeenth century. He writes:

The astonishing revival of interest in Arabic took place in other parts of Europe that had never known sustained contact with Muslim culture. By the early seventeenth century, centres of learning as far flung and as different in culture, outlook, and circumstances as Rome, Vienna, and London, or Breslau, Heidelberg and Paris, could boast of scholars with a knowledge of Arabic and collections of Arabic manuscripts that were wholly unprecedented in those parts. $^{2}$

Jones states that in spite of the presence of sizeable Muslim minorities, Spanish repression prevented them from playing an important role. Though this may be true, Moriscos nevertheless featured conspicuously in these formative years of Arabic and Islamic studies. $^{3}$ In exploring their role in Arabic and Islamic studies (here treated somewhat artificially as the «Western» study of Arabic) I shall expand on my previous writings in this field, ${ }^{4}$ in which I discussed a number of learned Moriscos who, after their expulsion as teachers, authors, translators and copyists of Arabic manuscripts and as diplomats and merchants, rendered services to Dutch scholars of Arabic. My question is why the works of a number of Moriscos involved in post-expulsion Arabic studies, mainly in North Africa, reveal an interest in the physical sciences, whereas little or no such interest is discernible among the Mudejars and Moriscos writing in the Iberian peninsula. First I want to determine whether the contrast itself is correct, and secondly, assuming that it is, how it can be explained. In discussing these questions, then, a distinction is made between Moriscos living in Iberia and those living in the Diaspora after the expulsion.

2 Jones, J.R., Learning Arabic in Renaissance Europe (1505-1624), unpublished $\mathrm{PhD}$ thesis, London University, SOAS, 1988, 23-24.

${ }^{3}$ Rodríguez Mediano, F., "Fragmentos de orientalismo español del s. XVII", Hispania, LXVI, 222 (2006), 243-276.

${ }^{4}$ See Wiegers, G.A., "Learned Moriscos and Arabic studies in the Netherlands, 16091624”, in J. Lüdtke (ed.), Romania Arabica, Tübingen, 1996, 405-417. 
It seems unlikely that during the sixteenth century, when Islam was repressed, Moriscos would have played a role in Arabic studies. The case of the well-known theologian, classicist and Semitist Nicolaas Cleynaerts (1493-1542) illustrates the point. At a time when there were no printed Arabic grammars and dictionaries, and few Arabic manuscripts were available, Cleynaerts, born in the southern Netherlands, taught himself Arabic largely by comparing it with Hebrew. In search of a teacher of Arabic he travelled to Spain, having heard about the Moriscos and hoping to find a teacher among them. He discovered, however, that Moriscos were unwilling to share their knowledge with him for fear of the consequences. ${ }^{5}$ This does not mean that Moriscos living in the peninsula did not play a role. Some did, albeit indirectly, for example after converting to Christianity. Juan Andrés is a case in point. Originally a Mudejar faqīh from Xàtiva, he converted to Christianity, became a canon of the Granadan cathedral (he is mentioned in the archival documents in about 1516), and in 1515, probably as a canon of the cathedral, published a polemical work in Spanish about Islam. ${ }^{6}$ This work reflects Andrés's profound knowledge of Arabic sources. The Confusión, as it was called, was soon recognized as an authoritative treatise, was translated into many languages, and became very influential among Arabists elsewhere in Europe. Guillaume Postel (15101581) praised it, Jacobus Golius (1596-1667) prepared a Latin translation, and the father of a more objective approach to Islamic

\footnotetext{
5 Toomer, G.J., Eastern Wisedom and Learning. The study of Arabic in seventeenthcentury England, Oxford, 1996, 41. Eventually Cleynaerts found a teacher in Granada. He bought a learned slave from Tunis, whose name was Kharūf. On the identity of this slave, see Koningsveld van, P.S., "Mijn Kharūf: Over de Arabische leermeester van Nicolaas Cleynaerts", Sharqiyyāt, 9, 2 (1997), 139-161; idem, “"Mon Kharūf': quelques remarques sur le maître tunisien du premier arabisant néerlandais, Nicolas Clénard (1493-1542)", Nouvelles approches des relations islamo-chrétiennes à l'époque de la Renaissance (Actes de la Troisième Rencontre Scientifique tenue du 14 au 16 mars 1998), Zaghouan, 2000, 123-141.

6 Andrés, J., Confusión o confutación de la secta Mahomética y del Alcorán, estudio preliminar Elisa Ruiz García, transcripción del texto María Isabel GarcíaMonge, Mérida, 2003. See review Wiegers, G.A., Aljamía. Anuario de información bibliográfica, 16 (2004), 254-261. It is still uncertain whether the author of this treatise was indeed a historical figure. The name Juan Andrés is mentioned, however, in a list of canons published by Marín López, R., El Cabildo de la Catedral de Granada en el Siglo XVI, Granada, 1998, 438. There can be little doubt that this is the author of the Confusión.
} 
studies, Adriaan Reland (1676-1718), even commended its usefulness for the study of Islam. ${ }^{7}$

Other Moriscos played a role, because they turned to the study of medicine, as will be seen below. The possession of Arabic medical texts, as opposed to Islamic texts, was not forbidden after the forcible conversion of Mudejars between 1499 and 1526. Moreover, the Arabic medical tradition remained practically relevant in the sixteenth century. Morisco physicians used Arabic texts in their practice of the medical profession. Some scholars have suggested that the unique possibilities that the study of medicine offered Moriscos in Granada to achieve high positions without being hindered by the limpieza de sangre statutes may explain why so many Granadan Moriscos chose to study medicine, besides the fact that the profession can be practised in many places - an additional benefit if one considers that many lived in exile. ${ }^{8}$

In his comparative studies of Arabic codices copied by various religious minorities in the Iberian peninsula P.S. van Koningsveld concludes that there are some interesting differences between Arabic manuscripts copied by Jews and Arabic codices copied by Mudejars and Moriscos. ${ }^{9}$ Whereas the Arabic manuscripts seem to include mainly Islamic materials of a religious nature, the Arabic texts circulated among the Jews were largely scientific. This suggests that in the Iberian peninsula Jews played a much larger role in scientific scholarship and medicine than Moriscos did. The Spanish and Aljamiado manuscripts, on the other hand, do not reveal a dif-

${ }^{7}$ Bobzin, H., The Qur'an im Zeitalter der Reformation. Studien zur Frühgeschichte der Arabistik und Islamkunde in Europa, Beirut, 1995, 79.

${ }^{8}$ García-Arenal, M. and Rodríguez Mediano, F., "Médico, traductor, inventor: Miguel de Luna, cristiano arábigo de Granada", Chronica Nova, 32 (2006), 187-231, 194. On Morisco medical practitioners, see García Ballester, L., Medicine in a multicultural society. Christian, Jewish and Muslim practitioners in the Spanish kingdoms, 1222-1610, Aldershot, 2001, especially essay VII, "A marginal learned medical world: Jewish, Muslim and Christian medical practitioners and the use of Arabic medical sources in late medieval Spain."

${ }^{9}$ Koningsveld van, P.S., "Andalusian-Arabic manuscripts from Christian Spain: a comparative intercultural approach", Israel Oriental Studies, 12 (1992), 75-110; idem, "Andalusian-Arabic manuscripts from medieval Christian Spain: some supplementary notes", Festgabe für Hans-Rudolf Singer: zum 65. Geburtstag am 6. April 1990 überreicht von seinen Freunden und Kollegen, 1 (FAS Publikationen des Fachbereichs Angewandte Sprachwissenschaft der Johannes Gutenberg-Universität Mainz in Germersheim, Reihe A, Bd. 13), Frankfurt am Main-Bern, 1991, 811-823. 
ferent pattern. The overwhelming majority of these manuscripts is of a religious and moral nature.

Van Koningsveld's article yielded some other important findings. It shed more light on official policies with regard to Arabic manuscripts and the ways the authorities employed people with a knowledge of Arabic. For example, one of the manuscripts he discusses is Ibn Rushd's Urjūza fì l-țibb, a medical text copied by Muhammad b. 'Alī b. Shihāb al-Ru'aynī. The manuscript is dated in the second decade of Rabí II 885 (i.e. $1480 \mathrm{CE}$ ) and was (so it appears from notes in the manuscript) inspected by a physician, Miguel Xeb, and a Jesuit called Jerónimo de Mur by order of Gregorio Miranda, apostolic inquisitor, judge and commissioner of the newly converted in the kingdom of Valencia. The note was signed by Martín de Ayala, archbishop of Valencia in $1566 .{ }^{10}$ It is well known that after the forced conversions the possession of Islamic texts was strictly forbidden for former Muslims. The goal of this inspection, therefore, was to determine whether a particular owner was entitled to possess them. It seems very likely that through inspections and confiscations Arabic manuscripts came into the possession of authorities and found their way into manuscript collections. We may assume that a steady stream of finds of Arabic and Aljamiado manuscripts required a need for expertise throughout the sixteenth century. In addition knowledge of Arabic was necessary for scholarly purposes, namely the study of the Arabic cultural and scientific heritage and for translating information given by informants, diplomats and those questioned by the Inquisition. Hence there was a need for Arabic expertise in sixteenth and early seventeenth century Spain.

A new episode began in 1588 with the demolition of an old tower in the city of Granada. The tower (later called the Torre Turpiana), probably once the minaret of the great mosque, had to make way for the new cathedral then under construction, which still stands. During the demolition a small chest was found in the rubble. It contained some bones, part of a veil, and a parchment on which was written a prophecy. The prophecy was attributed to St. John; the texts, in

${ }^{10}$ Koningsveld, "Andalusian Arabic manuscripts”, 100 (no. 70, Princeton University Library, Garrett Collection, MS 1094). The manuscript can be consulted online. On Mur, see Labarta, A., "Notas sobre algunos traductores de árabe en la Inquisición valenciana (1556-1609)", Revista del Instituto Egipcio de Estudios Islámicos, 21 (19811982), 101-133. 
Spanish, Arabic and Latin, were traced to a group of Christians who, it was suggested, had lived in Granada in the first century. Among the group was a bishop called Cecilius, whose name was mentioned on the parchment. The veil was purported to have belonged to Mary. ${ }^{11}$ There was enormous excitement. To grasp the magnitude of the find one must remember that the city of Granada did not possess any relics. The discovery would have compensated amply for such a lack. But soon the initial enthusiasm was tempered by scepticism or complete repudiation. Critics, among them the famous Spanish scholar Benito Arias Montano (1527-1598), pointed out that it was impossible for the parchment to be genuine, since, to begin with, Spanish had not yet evolved as a language in the first century. ${ }^{12}$

The interpretation of the parchment posed huge problems. The Arabic parts, allegedly historical narratives and prophecies, proved very difficult if not impossible to read. ${ }^{13}$ From the outset two Morisco interpreters were involved, Miguel de Luna ( $c a .1550-1615^{14}$ ) and Alonso del Castillo (ca. 1535-ca. 1610). Both owed a lot of their reputation as Arabic interpreters to the findings and both had studied medicine at the University of Granada. Alonso del Castillo became a licensed interpreter of Arabic in 1582 and compiled a catalogue of the Arabic manuscripts of El Escorial in $1574 .{ }^{15}$ Other Moriscos involved in the translations during these years were the Jesuit Ignacio de las Casas (1550-1608), Miguel de Ayala from Seville, ${ }^{16}$ Ahmad

11 See e.g. recent studies by Barrios Aguilera, M. and García-Arenal, M. (eds), Los Plomos del Sacromonte. Invención y Tesoro, Valencia-Granada-Zaragoza, 2006; idem, ¿La Historia inventada? Los Libros plúmbeos y el legado sacromontano, Granada, 2008.

${ }^{12}$ Cabanelas Rodríguez, D., "Arias Montano y los libros plúmbeos de Granada", MEAH, XVIII-XIX (1969-1970), 7-41.

${ }^{13}$ Koningsveld, P.S. and Wiegers, G.A., "El pergamino de la 'Torre Turpiana': el documento original y sus primeros intérpretes", in Barrios Aguilera and García-Arenal, Los plomos del Sacromonte, 113-139.

${ }^{14}$ On Miguel de Luna, see García-Arenal and Rodríguez Mediano, "Médico, traductor, inventor". The authors date Miguel de Luna's death to 1619. This date is a reading error of the documents in the archive of Sacromonte, Leg. V, f. 737 (letter discussing the "Christian" death of Miguel de Luna by Alonso Nuñez de Valdivia y Mendoça to archbishop Pedro de Castro, 10 December 1615. The letter is followed on f. 738 by an undated letter to Castro by doña María de Verástegui, his widow, confirming this).

${ }^{15}$ Cabanelas Rodríguez, D., El Morisco granadino Alonso del Castillo, Granada, 1991 (2nd edition, original edition Granada, 1965), 217.

16 His translations of the parchment of the Torre Turpiana and the Lead Books are preserved in the Archive of Sacromonte Abbey (Archivo de la Abadía del Sacramonte), Leg. VII, primera parte, f. 405r ff.

Al-Qanțara (AQ) XXXI 2, julio-diciembre 2010, pp. 587-610 ISSN 0211-3589 
b. Qāsim al-Hajarī from Hornachos (ca. 1570-after 1642, see below), and Lorenzo Hernández El Chapiz from Granada. ${ }^{17}$

Starting in the year 1595, seven years after the discovery of the chest in the ancient tower, a series of lead plaques with Arabic and Latin texts were found in caves in a mountain just outside Granada. These plaques were also accompanied by ashes and bones, which were said to be the remains of Christians who had been burnt there as martyrs under the Roman emperor Nero. The remains of Cecilius, the same person mentioned on the parchment in the ancient tower, were also found there. The texts were all said to have been written by two brothers from Arabia, Ibn al-Rādī and Thesifon $b$. 'Atțār, disciples of St. James, whose coming to Spain they confirmed. These books contained pseudo-acts of the apostles, creeds, prayers, and prophecies of an eschatological religious reformation and conversion of the whole world to one religion.

The ideas expressed in them were condemned by the Vatican in 1682 but remained alive among small groups of Moriscos, who probably managed to escape expulsion, and later generations continued to practise the Lead Book cult well into the eighteenth century, when such a group was discovered by the Inquisition. ${ }^{18}$ The secret

17 Wiegers, G.A., "Nueva luz sobre la identidad de Alonso de Luna, alias Muham$\operatorname{mad}$ b. Abī l- 'Āṣi y su proceso inquisitorial (1618)", in Barrios Aguilera and GarcíaArenal, Los plomos del Sacromonte, 403-417, n. 29; cf. García-Arenal and Rodríguez Mediano, "Médico, traductor, inventor", 191.

18 According to the records the group «Negaban asimismo la adoración de las imágenes de talla y pinturas, porque dicen ser éstas unos palos, a quien no se debe ve venerar [sic]. Dicen que sólo están en el cielo Habraham, Isaac y algunos santos que se veneran en quatro templos de esta ciudad, los quales se cree ser los s(an)tos del Monte s(an)to, y a éstos y no a otros ni a sus imágenes y pinturas se deben dar oración, por haver sido observantes de la secta de Mahoma sus descendientes, y que por él padecieron martirio en d(ich)o Sacromonte, y que en una piedra que está en d(ich)a Iglesia, en la qual los Christianos creemos piadosam(ente) que está enterrado un libro que trata de la puríssima conceción de María Santíssima, dicen ellos que en dicha está y contiene la verdadera explicación del Alcorán, y que este dicho libro no se manifestará hasta cierto año que en las causas se cita, en el qual se juntaría un concilio en la Chipre, al qual serán convocados todos los árabes; entonces, por alta providencia de su Profeta, se abrirá dicha piedra, entregando el dicho libro, que tantos años ha tiene encerrado para desengaño de los christianos y que reconozcan que sola su secta es la verdadera» (Epalza, M. de and Carrasco Urgoiti, M. a'S., "El Manuscrito 'Errores de los moriscos de Granada' (un núcleo criptomusulmán del siglo XVIII)", Fontes Rerum Balearum, III (1980), 235-247, 240. That the Lead Books played a religious role among the Moriscos in the sixteenth century appears from an Arabic prayer text, MS Biblioteca Nacional Madrid, Caja 18.602-18.603 (XXV): Allāhumma rabbanā ni'amanū bi-ḥaqq kalimatuka/bi-llatī 
cult was based on the expectation of a future revelation of the truth, to be disclosed at a council to be held in Cyprus. They believed that truth to be in harmony with Islamic teachings contained in the Sacromonte books.

Recent studies of the parchment and the Lead Books make it clear that, whatever their precise contents turn out to be when the original Arabic documents are edited, the books as a fruit of Morisco culture attracted the attention of a much larger public than ever before. In the years following their discovery a number of miracles associated with them drew attention not only in Europe but in other parts of the world as well. In addition the problems of their interpretation resulted in the involvement of a number of scholars, not only from Spain and other parts of Europe: capable translators were sought in the Islamic world as well. ${ }^{19}$ That led to a large number of publications about religious, philological and other aspects. ${ }^{20}$

In the late sixteenth and seventeenth centuries new ideas arose among the Moriscos. In a recent study Mercedes García-Arenal and Fernando Rodríguez Mediano discuss the discovery by the Inquisition of a collection of Arabic and Islamic manuscripts in the city of Pastrana in about 1630. The collection (now lost) had probably been left there by the Moriscos at the time of their expulsion. ${ }^{21}$ Pastrana was an important centre of Morisco activities. Most Moriscos living in Pastrana at the end of the sixteenth century were of Granadan origin and had migrated to Castile after the end of the civil war of 1569-1571. Among the manuscripts were both Arabic and Castilian codices. The scholar to whom we owe a description of this collec-

arsalti sayyidinā Yāsū rawhuka [sic] wa-bi-haqīqat il-injīl al-jalīl muzhiran fì dhì ljabal al-qudūs maktuban 'ala [sic] yād [sic] mawlatnā Maryam min kitāb al-makluba min al-'azamāt [...], in Barkaï, R., "Une invocation musulmane au nom de Jésus et de Marie", Revue de l'Histoire des Religions, CC, 3 (1983), 257-268; cf. Harvey, L.P., “A new Sacromonte text? Critical notes", Revue de l'Histoire des Religions, CCI, 4 (1984), 421-425, who corrects Barkaï's interpretation.

${ }^{19}$ On these miracles, see Kendrick, T.D., Saint James in Spain, London, 1960, 78.

${ }^{20}$ On these, see García-Arenal, M., "The religious identity of the Arabic language and the affair of the Lead books of the Sacromonte of Granada", Arabica, 56 (2009), 495528.

${ }^{21}$ García-Arenal, M. and Rodríguez Mediano, F., Un Oriente español. Los moriscos y el Sacromonte en Tiempo de Contrarreforma, Madrid, 2010 (forthcoming) Chapter 9, and their contribution in this volume. 
tion, Marcos Dobelio (who was, as we will see, also active in translating the Lead Books), identifies works such as the well-known Kitāb al-Shifā' by Qādī 'Iyād and the very popular Kitāb al-anwār by al-Bakrī. He also discusses an anti-Christian polemical text that deals with the attributes of God and stresses that Muhammad was the messiah predicted in Scripture. It is identified by them as the work of Muhammad Alguazir. Alguazir was a Morisco, who, as I have shown elsewhere, lived in Marrakesh in 1627 and was originally from Pastrana. The sources indicate that this work was written at the court of the Sadid Sultan Zaydān in about 1611. It is indeed a source of new religious ideas such as new conceptions of the messiah (i.e. that Muhammad was the messiah ${ }^{22}$ ), new ideas about rationalism and the relations between Islam and other religions derived from readings of the works of the famous Tilimsānī scholar al-Sanūsī, influences that had been absent in Morisco texts written in the peninsula. ${ }^{23}$ That his work now appears to have been known among the Moriscos in Pastrana itself confirms what we know about networks between Moriscos in the peninsula and those in the Maghrib, the Ottoman empire and the south of France in the years preceding the expulsion of $1609 .{ }^{24}$ Another work in the Pastrana col-

${ }^{22}$ Wiegers, G.A., "Muhammad as the messiah: a comparison of the polemical works of Juan Alonso with the Gospel of Barnabas", Bibliotheca Orientalis, LII, 3-4 (1995), 245-291.

${ }^{23}$ On Alguazir and his work, see Wiegers, G.A., "The Andalusī heritage in the Maghrib: the polemical work of Muhammad Alguazir (fl. 1610)", in O. Zwartjes, G.J. van Gelder and E. de Moor (eds), Poetry, politics and polemics. Cultural transfer between the Iberian peninsula and North Africa, Amsterdam-Atlanta, 1997, 107-132. Although it seems more likely that his work was written in Marrakesh, the possiblitity cannot be ruled out that Alguazir wrote it in the peninsula before the expulsion. García-Arenal and Rodríguez Mediano (Un Oriente Español and contribution in this volume) believe that the author is identical with one Diego Alguacil who was tried by the Inquisition in 1613. This seems to indicate that they believe he was still in Spain when he wrote the polemical work. On the other hand Wiegers, G.A., A learned Muslim acquaintance of Erpenius and Golius. Ahmad b. Qāsim al-Andalusi and Arabic studies in the Netherlands, Leiden, 1988, 43, discusses a letter by al-Hajarī, dated 1611, which refers to a Alguazil, who was at that time in Marrakesh and was also identified as the author of the polemical work. It is hard to imagine that the Moroccan sultan would order a Morisco living in Pastrana at the time to write a polemical work. That Alguazir wrote it at the order of the sultan is mentioned in all extant manuscripts.

${ }^{24}$ Wiegers, G.A., "Managing disaster. Networks of Moriscos during the expulsion of 1609", Journal of Medieval Religious Cultures (forthcoming); Bouzineb, H. and Wiegers, G.A., "Tetuán y la expulsión de los moriscos", Tițān khilāl al-qarnayn 16 wa17, Tetuan, 1996, 73-108; Bernabé Pons, L.F., "Notas sobre la cohesión de la comunidad morisca más allá de su expulsión de España”, Al-Qanțara, XXIX, 2 (2008), 307-332. 
lection, entitled Kitāb al-asrār fi funūn madhāhib al-shatțār wa-hum al-tayaliq , is described by Dobelio as follows:

Libro de los secretos de diferentes maneras de operaçiones de los Príncipes de los Demonios, donde introduçe un Príncipe dellos llamado Phitecus [Ar. Phayqaytūs, GW], y diçe hauer sido el primero que diò obediencia al Rey Salomón aconsejándole que llamase a su presençia los 72 Príncipes de las Legiones para interrogar a cada uno de por sí del daño que haze al género humano, y que enseñe el remedio. Todos estos después de hauer entrado a su presençia diçen el mal que hazen, después dan el remedio de cosas naturales acompañadas de Caracteres, Nóminas, Sigilos, y palabras superstiçiosas del Alcorán; donde se descubre hauerlo compuesto algún Mahometano y para acreditar su patraña, lo apoya al Rey Salomón. ${ }^{25}$

The authors connect this work with the Lead Books (as Dobelio does himself), suggesting that the magical tradition discussed in the manuscript can be found in the book called History of the Seal of Solomon. ${ }^{26}$ However, judging by its title and the brief description (which is all we have left), the text seems identical with an early fifteenth century Arabic manuscript found several years ago in Ocaña and studied and published by Joaquina Albarracín Navarro and Juan Martínez Ruiz. ${ }^{27}$

After the expulsion of 1609, besides many religious texts (most of them written in Spanish in Latin script ${ }^{28}$ ) we witness the activities of a number of Moriscos at the beginning of the seventeenth

${ }^{25}$ On the Kurdish Arabist Dobelio, see Rodríguez Mediano, F. and García-Arenal, M., "De Diego de Urrea a Marcos Dobelio: intérpretes y traductores de los 'Plomos", in Barrios Aguilera and García-Arenal, Los plomos del Sacromonte, 297-334.

${ }^{26}$ On the Seal of Solomon as a magical (i.e. esoteric) symbol, see especially Roisse, $\mathrm{Ph}$., "L'Histoire du Sceau de Salomon ou de la Coincidentia oppositorum dans les livres de plomb", Al-Qantara, XXIV, 2 (2003), 359-408. A corrected and updated version was published in Spanish as "La Historia del Sello de Salomón: Edición crítica y traducción comparada", in Barrios Aguilera and García-Arenal, Los plomos del Sacromonte, 141-171. On an important Aljamiado magical text, MS 22 of the Almonacid collection, see Labarta, A. (ed.), Libro de dichos maravillosos (Misceláneo morisco de magia y adivinación), Madrid, 1993; see also "Sulaymān", $E I^{2}$, sub voce.

${ }^{27}$ See e.g. Albarracín Navarro, J. and Martínez Ruiz, J., Medicina, farmacopea y magia en el "Misceláneo de Salomón" (Texto árabe, traducción, glosas aljamiadas, estudio y glosario), Granada, 1987, 39.

${ }^{28}$ On this religious literature, see Cardaillac, L., Morisques et Chrétiens, un affrontement polémique (1492-1640), Paris 1977, passim; Wiegers, G.A., Islamic literature in Spanish and Aljamiado: Yça of Segovia (fl. 1450), his antecedents and successors, Leiden, 1993, 185-196.

Al-Qanțara (AQ) XXXI 2, julio-diciembre 2010, pp. 587-610 ISSN 0211-3589 
century in a phenomenon that Muhammad al-Mannūnī calls a «movement of translations into Arabic» at the Sa'did courts, not only of al-Manșūr but also of his son Zaydān. ${ }^{29}$ According to alMannūnī five factors influenced this movement: the migrations of the Mudejars and Moriscos; the influence of Maghribi Muslim captives who, after living in Christian territories long enough to learn the languages, had returned to North Africa; contacts between inhabitants of the Maghrib states and inhabitants of the presidios under foreign domination nearby; the influence of high officials and sultans who were interested in these matters and knew Spanish; and finally, the desire to know Renaissance Enlightened ideas. In this context al-Mannūnī discusses inter alia the physician Abū 1-Qāsim al-Wazīr al-Ghassānī (1547/955-1611/1019), the physician Abū 1Qāsim al-Mașfīwī (born 1560/968), and the learned diplomat Ahmad b. Qāsim al-Hajarī. We can probably add others to this list, such as 'Alī b. Ibrāhīm al-Qurțubī, physician at Zaydān's court, who composed several Arabic poems and possibly based his practice on medical knowledge acquired in Spain: he had been born in Cordova, where he had practised medicine. ${ }^{30}$ Of the aforementioned persons Aḥmad b. Qāsim al-Ḥajarī is obviously the best known. In his Nassir al-dīn (a work of which only fragments were known at the time al-Mannūnī wrote) he also sheds light on the scientific atmosphere at court. ${ }^{31} \mathrm{He}$ tells us about a translation he made on Zaydān's orders of a geographical work in Latin, ${ }^{32}$ on which, because he did not know Latin himself, he collaborated with a captive monk. ${ }^{33}$ The aforementioned Muhammad Alguazir, who also seems to have belonged to the category described by al-Mannūnī, wrote,

29 Al-Mannūnī, M., "Zāhira tárībiyya fì 1-Maghrib al-Sa diyya", Revista del Instituto Egipcio de Estudios Islámicos en Madrid, XI-XII (1963-1964), 329-358.

${ }^{30}$ MS in private possession, p. 149: al-andalusī al-iqlīm, al-qurtubì al-manshā', alumaw̄ al-nasab, al-Marrākushī al-dārr; see also al-'Alawī, 'Abd Allāh Binnașr, " Ilm altaghdiya fì al-turāth al-maghribī min khilāl urjūzat al-fawākih al-sayfiyya wa-l-kharīfiyya liAbī l-Hasan b. Ibrāhīm al-Andalusī al-Marrākushī’, Da'wat al-Haqq, 40, 334 (1420/1999), 115-129.

${ }^{31}$ Al-Ḥajarī, Aḥmad b. Qāsim, Kitāb nāṣir al-dīn 'alā l-qawm al-kāfirīn (The supporter of religion against the infidels). Historical study, critical edition and annotated translation by Van Koningsveld, P.S., Al-Samarrai, Q. and Wiegers, G.A., Madrid, 1997 [Fuentes Arábico-Hispanas, 21] and the literature cited.

${ }_{32}$ Al-Hajarī, Kitāb nāṣir al-dīn, 151.

${ }^{33}$ Ibid., 233.

Al-Qanțara (AQ) XXXI 2, julio-diciembre 2010, pp. 587-610 ISSN 0211-3589 
as we have seen, an anti-Christian polemic text at the court of Zaydān, which circulated in a Latin version among anti-trinitarians in England and the Dutch Republic. ${ }^{34}$ The work drew the attention of Thomas Erpenius, who is said to have worked on a translation as well. ${ }^{35}$

It is surprising to see the number of Moriscos involved in the «physical sciences» compared to the profile sketched above. But maybe it is not so surprising, if we consider that natural philosophies and magic were closely linked to contemporary forms of physical science, in particular in the medical profession. Moreover, Thomas Glick has drawn our attention to processes of technological diffusion, to which Moriscos and Marranos, because of their background, contributed. ${ }^{36}$ According to García Ballester, whose studies in this field were mentioned above, as the sixteenth century progressed Morisco physicians increasingly worked in a way that this scholar describes as «empirical», that is they made use of religious and magic ideas and techniques in their practice, which is one reason why the functions of medical practitioner and the faqih were often hard to distinguish. ${ }^{37}$ But that is not all. Another aspect may be that both magic and physical science work on the assumption that humans are able to acquire power over and knowledge of the natural world, a world which, to many thinkers influenced by esoteric ideas, cannot be detached from God and might even be identical with him. The esoteric tradition features in the Lead Books and is exemplified by the symbol of the khätam Sulaymān (the Seal of Solomon). The story of Sulaymān's knowledge of magic is narrated

${ }^{34}$ See Wiegers, "The polemical work" and Mulsow, M., "Socinianism, Islam and the Radical Uses of Arabic Scholarship", Al-Qantara (this volume), 549-586. On antitrinitarianism, also see the valuable article by Mout, M.E.H.N., "Calvinoturcisme in de zeventiende eeuw. Comenius, Leidse Orientalisten en de Turkse Bijbel", Tijdschrift voor geschiedenis, 91 (1978), 576-607.

35 Wiegers, "Learned Moriscos", 409.

${ }^{36}$ Glick, T., "Moriscos and Marranos as agents of techonological diffusion", History of Technology, 17 (1995), 113-125.

${ }^{37}$ García Ballester, L., "Academicism versus empiricism in practical medicine in sixteenth-century Spain with regard to Morisco practitioners", in A. Wear, R.K. French and M. Lonie (eds), The medical Renaissance of the sixteenth century, Cambridge, 1985, 246-270, 248, reprinted in idem, Medicine in a multicultural society. Christian, Jewish and Muslim practitioners in the Spanish kingdoms, 1222-1610, Aldershot, 2001, essay VIII. It is important to see that the empirical method here seems to mean something quite different than in the works of Dijksterhuis and Cohen discussed below. 
in the Lead Book entitled Ta'rīkh khātam Sulaymān (History of the Seal of Solomon) and texts in the Mudejar manuscript of Ocaña (see above).

In the West the Muslim world was even seen as a Mecca of magical knowledge and power. This is illustrated by an event in 1614. I am referring to the publication in Germany of the so-called Fama Fraternitatis, one of the founding documents of the fraternity of Rosicrucians. The Fama tells about the German Christian Rosencreutz, a fourteenth century knight, whose quest for the wisdom of Adam, Moses and Solomon and his desire to bring about a general reform of the world brought him to Fez in the Arab world - the region where, according to him, esoteric wisdom had passed from the Hebrew prophets, Egypt, Greece and Rome onwards. Arabic Magia and the Cabala are mentioned in this regard, as well as mathematics and physics. Rosenkreutz travelled back north via Spain. ${ }^{38}$ In the pamphlet it is told that brother Rosencreutz compiled a number of philosophical works, including one translated from Arabic, the book M. [sic], which Paracelsus had studied, and he constructed a magical language and script. Shortly before his death he built a sacred vault, the door of which would be opened after 120 years and would lead to the beginning of the public activities of an - until that moment - secret society that would bear his name. The Fama Fraternitatis is optimistic about the powers of reason as divinely inspired power. This «reason» is ascribed to adherents of other faiths as well, even though the pamphlet states that Arabian magic is not as pure as Western forms in fathoming the mysteries of nature. ${ }^{39}$ The Rosicrucian pamphlets show that Europe saw the Islamic world as a source of magic, an image that arose in the early Middle Ages.

In Western tradition magic, esotericism and hermeticism were an undercurrent, closely related to interest in a philosophy of nature and the physical sciences, which had not yet started their dazzling development at that time but were becoming manifest despite pressure from orthodox Christianity. The latter considered the a priori supposition that humans are capable of studying the natural world,

${ }^{38}$ Dickson, D.D., The Tessera of Antilia: Utopian brotherhoods and secret societies in the early seventeenth century, Leiden, 1998, 73-74; Von Stuckrad, C.K.M., Western Esotericism. A brief History of Secret Knowledge, London-Oakville, 2005, 113-114.

${ }^{39}$ Dickson, The Tessera of Antilia, 75. 
including its divine dimensions, through the use of reason and empirical research to be contrary to Christian teaching. In the Western world the interest in the hermetic tradition and its neo-Platonic philosophical ideas went hand in hand with a positive valuation of the prisca theologia, that is pre-Christian religious thought, which in orthodox Christian circles had always met with suspicion. In that perspective it should be noted that the Seal of Solomon not only symbolized the magical traditions of Islam, but also had such ancient roots as the magen David (shield of David) in the magical traditions of Judaism, and had come to serve as an occult symbol in all three monotheist religions. As such, it may have appealed to the ideal of a unity transcending the historical religions of the time and hence the social and cultural opposition that divided Spain and the Western world, and was perhaps part of a strategy used by the anonymous authors to achieve their goal of justifying the existence of Morisco minorities in Spain on ideological grounds. ${ }^{40}$ It is also possible that the authors of the Lead Books had a genuine interest in these esoteric ideas. The idea of a unity underlying the historical religions was shared in several circles of thinkers that emerged in places spread across Europe, including the Dutch Republic. ${ }^{41}$ It was here that Moriscos were most active as informants and teachers of Arabic.

\section{The Dutch Republic, Moriscos and Arabic studies}

The Republic was, in the words of David Sorkin, a confessional state with a «public church» and a dominant clergy, whose religious plurality (Mennonites, Lutherans, Catholics, Jews, Socinians, Quakers) was the «unforeseen and unfortunate result of the reformation and the Dutch Revolt, which prioritized social «concord» preventing either the Reformed Church or the Catholic Church from imposing confessional unity». ${ }^{42}$ From the end of the sixteenth century onwards the Dutch tried to establish treaties with several Muslim powers,

40 Scholem, G., "The star of David: history of a symbol", in idem, The messianic idea in Judaism and other essays on Jewish spirituality, New York, 1971, 257-281, 267.

${ }^{41}$ See for example Rekers, B., Arias Montano, Madrid, 1973.

42 Sorkin, D., The religious Enlightenment. Protestants, Jews, and Catholics from London to Vienna, Princeton-Oxford, 2008, 6-7. 
notably Morocco and the Ottoman empire. Dutch motives for establishing friendly relations with Morocco were closely connected with their common hostility to Spain. After some initial, rather shaky attempts, hindered by the civil strife in Morocco after the death of sultan Ahmad al-Manșūr in 1603, some encouraging results were achieved after one of al-Manșūr's sons, Mawlāy Zaydān, acceded to power in Marrakesh in about 1608. With him the Dutch were to establish stable relations. As a token of their good intentions the Dutch sent Zaydān three warships he had requested. ${ }^{43}$ This marked the beginning of a series of negotiations, culminating in a treaty of friendship and free commerce in December 1610, which also provided for «free access and friendly reception for their respective subjects without need for any safeguards or safe-conducts, no matter how they come to the other's territory». ${ }^{44}$

At the end of the sixteenth century the study of Hebrew and Arabic was introduced in such cities as Leiden, which had been granted a university in 1575, and Amsterdam, where the inn keeper and printer Jan Theunisz started studying these languages and printing Hebrew books. ${ }^{45}$ At the recently founded University of Leiden the famous Josephus Justus Scaliger (1540-1609) played a prominent role, ${ }^{46}$ along with learned Muslims and Jewish informants and teachers. Jan Theunisz, a Mennonite (hence not belonging to the dominant Reformed Church), started studying Arabic under the guidance of the famous Franciscus Raphelengius in Leiden and was a fairly accomplished Arabic scholar when, in 1610, he coincidentally met 'Abd al-'Azīz b. Muhammad al-Taghlibī in Amsterdam, as we will see below.

43 Wiegers, "Learned Moriscos".

${ }^{44}$ Weiner, J.C., Fitna, corsairs, and diplomacy. Morocco and the maritime states of Western Europe, 1603-1672, unpublished PhD thesis, Columbia University, 1976, 255.

${ }^{45}$ Wijnman, H.F., "De Hebraïcus Jan Theunisz. Barbarossius alias Johannes Antonides als lector in het Arabisch aan de Leidse Universiteit (1612-1613). Een hoofdstuk Amsterdamse geleerdengeschiedenis", in Studia Rosenthaliana, II, 1 (1968), 1-41, and 2 (1968), 149-177.

${ }^{46}$ On Arabic studies in the Netherlands, see e.g. Juynboll, W.M.C., Zeventiendeeeuwsche beoefenaars van het Arabisch in Nederland (Diss. Utrecht), Utrecht, 1931. On Leiden University, see Brugman, J., "Arabic scholarship", in Th.H. Lunsingh Scheurleer and G.H.M. Posthumus Meyes (eds), Leiden University in the seventeenth century. An exchange of learning, Leiden, 1975, 203-215. On Muslims in the Dutch Republic, see Kaplan, B.J., Muslims in the Dutch Golden Age. Representations and realities of religious toleration, Amsterdam, 2006. 
After the initial contacts Zaydān sent several envoys to the Dutch Republic to negotiate the aforementioned treaty. The first was Hammū b. Bashir. He came in the company of Samuel Pallache, a Moroccan Jew from Fez, whose family was to play an important role in Sadid relations with the Low Countries and who was secretary to Zaydān, 'Abd al-'Azīz b. Muhammad al-Taghlibī. ${ }^{47}$ In Amsterdam this secretary coincidentally met the aforementioned Jan Theunisz, and stayed with him in his house even after the embassy had left for Morocco. They had frequent, frank and friendly discussions about religious matters, and their meeting resulted in a polemical work about Christology in Arabic and Latin, entitled Inquisitio et reponsio quae fuit inter Mahumetistam et Christianum de Mesia ad intelligendum an ille sit filius Dei, nec ne ("Investigation and its response, which has come about [in a discussion] between a Muhammedan and a Christian in order to understand whether or not the Messiah is the Son of God"). In 1610 Theunisz offered the manuscript to the States General as proof of his fluency in Arabic. In addition to the polemic itself (on f. 50v-87r) it includes the story of his meeting with 'Abd al-'Azīz b. Muhammad (f. $5 \mathrm{v}-17 \mathrm{r}$ ); some translations from süra 3, especially the parts on Jesus (f. $22 \mathrm{v}-32 \mathrm{v}$ ); a Christian creed by Theunisz (f. 34r-43r, and on f. 32v$33 \mathrm{v}$ the Apostolic creed); and a Muslim creed by the said secretary (f. $44 \mathrm{v}-49 \mathrm{v})$. A prominent feature of the Muslim creed, as well as the discussion about Jesus, is an enumeration of Muhammad's miracles, very likely based on Qāọī 'Iyāḍ's Kitāb al-Shifă'. ${ }^{48}$

In the same year, 1610, the Moroccan ambassador Ahmad b. 'Abd Allāh al-Hayț̣ was invited by the Stadholder, Maurice, to a splendid banquet (splendida mensa) in The Hague. During this banquet, Maurice, a Protestant, and his Catholic brother-in-law Immanuel of Portugal questioned him about the Muslim view of Jesus. He had two reasons, he explained, to answer «now» rather than on that occasion. First of all, the moment had not been suitable. An important question like that could not be answered satisfactorily in the course of a banquet (inter prandendum). Secondly, he felt that he first needed to con-

${ }^{47}$ Wijnman, "De Hebraïcus", 6, bases himself on Lévi Provençal, E., Les historiens des chorfa, Casablanca, 1991, 402; al-Nāṣinī, Abū l-'Abbās Ahmad b. Khālid, Kitāb al-istiqsā' li-akhbār duwal al-Maghrib al-Aqșā, al-Dār al-Baydā', 1955, VI, 72, has 'Abd al-'Azīz b. Muhammad al-Taghlibī, cf. Hajji, M., L'Activité intellectuelle au Maroc à l'époque Sa'dide, Rabat, 1976-1977, 14.

${ }^{48}$ Regional Archives, Leiden, Library, MS 69.501. 
sult sources such as Qur'ānic commentaries (interpretatio sancti Alcorani), the works on the unity [the tawhìd, i.e. theological works] by the very learned «Zidi Mehemet Elemuci» (probably al-Sanūsī, mentioned above) and «Zidi Mohamet Eleir», probably the Morisco Muhammad Alguazir, mentioned above. The answer, in the form of a polemic, was sent in about 1612: the Latin text, as I have shown elsewhere, is largely identical with the anti-Christian polemic by $\mathrm{Mu}-$ hammad Alguazir.

Theunisz was a scholar of Hebrew as well, and in 1605 and 1606 he printed several books by Hugh Broughton (1549-1612), an Englishman living in the Netherlands at the time, and tried to convert Jews to Christianity. ${ }^{49}$ Not surprisingly in view of their expertise in scientific lore in Arabic (as appears from Van Koningsveld's studies quoted above), Jews and Conversos were sought after as teachers of Arabic. ${ }^{50}$ In addition to other Jews, some members of the Pallache family also brought Arabic learning to the Netherlands. In about 1611 Erpenius heard rumours that the curators of Leiden University were considering appointing a Moroccan Jew, proficient in Hebrew and Arabic, as professor of Arabic at Leiden University. ${ }^{51}$ It is not clear who the person in question was, but it seems likely that we are dealing with either Isaac or Moses Pallache. Moses and Isaac were both sons of Joseph Pallache. Moses was born in $1592^{52}$ and was therefore too young. Possibly it was Isaac, about whom we know that he actually had ambitions to teach Oriental languages at Leiden University. He converted to Christianity in 1627 in a village near Utrecht, and had his son Joseph baptized at the Hooglandse Kerk in this city in the presence of Constantijn l'Empereur, professor of Hebrew, and Franciscus Burgersdijck, then rector magnificus of Leiden University. ${ }^{53}$

Several Arabic scholars have described the motives for studying Arabic at the time. Theunisz discusses these briefly and succinctly,

49 Wijnman, "De Hebraïcus", 12.

${ }^{50}$ See also Russell, G.A., "The seventeenth century: The age of 'Arabick', in idem (ed.), The 'Arabick' interest of the natural philosophers in seventeenth-century England, Leiden, 1994, 1-19, 6.

51 Wijnman, "De Hebraïcus", 150.

52 Ibid., 151.

53 García-Arenal,M. and Wiegers, G.A., Un hombre en tres mundos. Samuel Pallache, judio de Fez entre la Europa Católica y la Protestante, Madrid, 2007, 181-182. 
stressing, as others did, the use of Arabic for learning Hebrew, thus highlighting their close relationship. Arabic is a very old and useful language

for merchants and travellers in Africa, Asia, and many parts of Europe [sic! GW] but also those who are interested in ancient philosophy and the divine languages, since, with the use of this language, the most important writings of theologians, physicists, physicians and mathematicians can be understood. Many writings that have been poorly translated into other languages, can, with the knowledge of Arabic, be improved; others, that have long been thought to be lost, can be retrieved from the underworld, and thereby light can be shed on the Hebrew sources of the Bible. In addition, many souls that have been lost to Satan, can be saved for [the service of] our Messiah [...]. ${ }^{54}$

Such motives were adduced by other Arabic scholars as well. Interest in Arabic and Hebrew were loosely related. Many believed that Arabic would be an aid to understanding Hebrew, considered to be the original language of humankind spoken by Adam and Eve in the garden of Eden. ${ }^{55}$ Interest in the physical sciences is also conspicuous and explains why the early Arabists acquired a number of wide ranging Arab manuscripts, including texts dealing with the physical sciences, natural philosophy, the occult sciences and magic. As mentioned in my earlier publications, al-Hajarī met several European scholars during his travels in Europe, including the French Orientalist Etienne Hubert, whom he met several times in France, ${ }^{56}$ and the Leiden professor of Arabic Thomas van Erpen (Erpenius), whom he met in Paris and Leiden between 1611 and $1613 .{ }^{57} \mathrm{He}$ probably stayed with Erpenius in his house in Leiden for some time. Some years ago the Leiden scholar Jan Schmidt discovered two hitherto unknown letters by al-Hajarī written to the Leiden Arabists among the Rylands papers kept in Manchester University library. They are found in a manuscript which contains a large number of letters exchanged by Leiden Orientalists and their Middle Eastern correspondents. ${ }^{58}$

${ }^{54}$ Wijnman, "De Hebraïcus", 19. On these motives, also see Juynboll, Zeventiendeeeuw-sche beoefenaars.

${ }_{55}$ Olender, M., Les langues du paradis. Aryens et Sémites. Un couple providentiel, Paris, 1989, 13-15.

${ }_{56}$ Al-Hajarī, Kitāb nāsisir al-dīn, 31, 36.

57 Wiegers, A learned Muslim acquaintance.

${ }^{58}$ Schmidt, J., "An ostrich egg for Golius. The Heyman papers preserved in the Leiden and Manchester University Libraries and early modern contacts between the Netherlands 
A first letter in the Rylands papers is directed to «Monsuor Arpenius flamenco.» According to Schmidt the said letter discusses «[...] the value of learning ( ${ }^{\mathrm{i}} \mathrm{lm}$ ) in the Islamic tradition, the qualities of the Arabic language, and the interpretation of certain Koranic expressions. A number of important works on grammar and rhetoric are mentioned». ${ }^{59}$

A second letter in the Manchester collection, written from Marrakesh to the Leiden Arabist Jacobus Golius by al-Hajarī, is dated 12 Rabī $^{\mathrm{e}}$ 1, 1033 (2 February 1624). The main subject is Ibn Baklārish's Kitāb al-Musta 'īñ̄'. ${ }^{60}$ In the correspondence several other Moriscos are mentioned as informants and suppliers of Arabic manuscripts. ${ }^{61}$ Through diligent work and aptitude the Leiden Arabists were able to make rapid progress in the study of Arabic. No wonder, then, that in 1623 the bishop of Granada called on Erpenius to translate the Lead Books. However, even though Erpenius did some initial work, he did not go to Spain. ${ }^{62}$

From the foregoing it seems that in the last years before the expulsion and the years after 1614 Morisco intellectuals became involved in what can be called a cultural movement, of which philological learning is a major aspect alongside the physical sciences, geography, and natural philosophy. In conceptualizing Arabic studies in the seventeenth century one should not forget that the natural scientists were often none other than the philologists and historians. Both Thomas Erpenius and Jacobus Golius had studied mathematics and linked their studies of Arabic to their interest in the physical sci-

and the Middle East", in idem, The joys of philology. Studies in Ottoman literature, history, and Orientalism (1500-1923), vol. II, Orientalists, Travellers and Merchants in the Ottoman Empire, Political Relations between Europe and the Porte, Istanbul, 2002, 9-74.

${ }_{59}$ Schmidt, "An ostrich egg", 17; Houtsma, M.Th., "Uit de Oostersche correspondentie van Th. Erpenius, Jac. Golius en Lev. Warner. Eene bijdrage tot de geschiedenis van de beoefening der Oostersche letteren in Nederland", Verhandelingen van de Koninklijke Akademie van Wetenschappen, XVII, Amsterdam, 1888.

${ }^{60}$ See on this letter Witkam, J.J., "The Leiden manuscript of Kitāb al-Musta' in $\vec{\imath}$ ", in Ch. Burnett (ed.), Ibn Baklarish's book of simples. Medical remedies between three faiths in twelfth-century Spain, London, 2008, 75-94.

${ }^{61}$ We can only briefly mention them here: 'Alī b. Ibrāhīm al-Andalusī al-Gharnātị alMarrākushī (Houtsma, o.c., 47) and al-Ḥāij Muhammad b. Sa ${ }^{1} \overline{1}$ al-Andalusī (Schmidt, "An ostrich egg", 28).

${ }^{62}$ Martínez Ruiz, J., "Cartas de Thomas van Erpen (Thomas Erpenius) en un archivo de Granada (1623-1624)", BRAE, LV (1975), 265-306 (includes photos). 
ences and mathematics. In 1629 Golius succeeded the astronomer and mathematician Willibrord Snellius (1580-1626) as professor of mathematics at Leiden University and was also involved in astronomy, including the building of an observatory. This is what Russell describes as the "natural interest of "Arabick"»: Arabic was the medium through which one got access to theories about what we nowadays see as religious and natural knowledge that had been passed on to the Arabic world. At the time, the present-day distinctions and categories did not yet exist but in precisely this period current ideas were changing rapidly. The period we are discussing here saw a change that has been aptly characterized by the Dutch scholar E.J. Dijksterhuis as «the mechanisation of the world picture». ${ }^{63}$ We have seen above that religion, especially in the form of magic, also played a part in these developments. But whereas some physical scientists and natural philosophers turned to esoteric thought (e.g. Isaac Newton), others, among them philologists of a more orthodox Christian persuasion, became critical of these ideas. Isaac Casaubon, for example, criticized the dating of the Corpus Hermeticum, arguing that it dated from the early Christian rather than the ancient Egyptian period. ${ }^{64}$

We now turn to source materials that illustrate how Moriscos experienced these developments and were to some extent involved in them. The following passage by al-Hajarī, a crucial figure for Moriscos in the Diaspora, is very interesting in this respect. This passage about his stay in France, where he had gone to recover goods stolen from Moriscos on board French ships, can be found in his Nāșir al-dīn. In it alHajarī compares astrology/astronomy in France and Morocco:

As for the goods deposited in Bordeaux, which had been stolen by the captain from the people of al-Hajar al-Ahmar, ${ }^{65}$ I got hold of them after one and

${ }^{63}$ See Jones, Learning Arabic., passim; Russell, "The seventeenth century"; Dijksterhuis, E.J., The mechanisation of the world picture, Oxford, 1961. See also the recent comparative study by Cohen, F.H., De herschepping van de wereld. Het ontstaan van de moderne natuurwetenschap verklaard, Amsterdam, 2008 (in Dutch, to be published in English as How modern science came into the world), 187-189.

${ }^{64}$ Grafton, A., "Protestant versus prophet. Isaac Casaubon on Hermes Trismegistus", Journal of the Warburg and Courtauld Institutes, 46 (1983), 78-93.

${ }_{65}$ The Spanish name of this place is Hornachos; see Boyano Guerra, I., "Al-Haŷarī y su traducción del pergamino de la Torre Turpiana", in Barrios Aguilera and GarcíaArenal, ¿La historia inventada?, 137-157. In a recent article, "Tierra de Barros, tierra de al-Hajarī Bejarano", Ismail El Outmani argues that al-Hajar al-Ahmar is the region in Extremadura called Tierra de Barros («clay country»), a region which in fact includes the 
a half years had gone by. Praise be to God that every Andalusian who appointed me as his legal representative, received some money [in compensation]. After I had arranged my affairs in Bordeaux, I returned to Paris, the city of the Sultan. There I met the greatest astronomer [well-trained] in the science of the stars. He told me: 'I never saw any result of this science in practice. I have tested many of the hypotheses and I did everything possible to verify the calculations and to measure the altitude of the constellations when ascending, in accordance with the prescriptions of the authors. I possess more than a hundred works concerning this art and I understand their contents. When the father of Louis, who is now Sultan, ${ }^{66}$ was killed. ${ }^{67}$ I said to myself: the Sun to which authority over the Sultans is ascribed, should have been connected to Misfortune in that hour. But when I looked for that, I found it connected to Venus which means good fortune. When the sun is connected to Venus this means that the Sultan can be subject only to good fortune. The scholars who laid down this system did not produce any rules that can be applied successfully in accordance with their own prescriptions. Nay, I find the matter to be contrary to what they pronounce'. End [of quotation].

I say: you should know that I studied the science of the ahkām to some extent under the supervision of the faqīh Ahmad al-Mașyūb al-Fāsī, who was Andalusian by origin. He was an outstanding expert in the sciences of astrology, alkhatt al-ramli, and of the tables with ciphers and letters. He possessed a great number of books on those arts, because I believe that Moulay Ahmad ${ }^{68}$-may God have mercy upon him! - made the books of his library available to him, of which it is said that the total number were thirty-two thousand. This shaykh - may God have mercy upon him! — said to me repeatedly: 'When the Sultan asks me something about matters that are hidden, I leave the books for what they are, make a fivefold table and fill it with five of the names of the Exalted God, viz: Al-Hādì, Al-Khabìr, Al-Mubìn, 'Allām and al-Ghayyūb, arranging them in such a manner that they can be read vertically, horizontally and diagonally, in the following way:

\begin{tabular}{|l|l|l|l|l|}
\hline Al-Hādī & al-Khabīr & Al-Mubīn & 'Allām & Al-Ghayyūb \\
\hline 'Allām & Al-Ghayyūb & Al-Hādī & Al-Khabīr & Al-Mubīn \\
\hline Al-Khabīr & Al-Mubīn & 'Allām & Al-Ghayyūb & Al-Hādī \\
\hline Al-Ghayyūo & Al-Hādī & Al-Khabīr & Al-Mubīn & 'Allām \\
\hline Al-Mubīn & 'Allām & Al-Ghayyūb & Al-Hādī & Al-Khabīr \\
\hline
\end{tabular}

Then I study the sum of all the letters with the help of al-jazm al-kabìr. After I finish my study in the night, before going to sleep, I put the table under my

village of Hornachos, published on http://moriscostunez.blogspot.com/2010/01/tierra-debarros-tierra-de-al-hayari.html (consulted on 11-6-2010).

${ }^{66}$ Louis XIII, king of France.

${ }^{67}$ I.e. the killing of Henry IV.

${ }^{68}$ Aḥmad al-Manșūr al-Dhahabī (reigned 1578-1603).

Al-Qanțara (AQ) XXXI 2, julio-diciembre 2010, pp. 587-610 ISSN 0211-3589 
head. Then someone appears to me in my dream to inform me about the answer, as I had in mind to mention frankly what I was in need of.' He [also] said that he was truthful in the answers he gave. - One may suppose, however, that he used to make a calculation concerning the issue at stake in order to show it, so that [the Sultan] would think that he extracted the answer from it. On the basis of my birth-date, two major astrologers in Seville ruled that my life-time would last between forty and fifty years. Shaykh Ạ̣mad al-Mașūb in Marrakesh found sixty-six years. Today I have reached seventy-four lunar years, and I am still enjoying the grace of the Exalted God. ${ }^{69}$

This quotation from al-Hajarī’s Nāṣir al-dīn, a work composed in about 1637, gives us an amusing glimpse into the transformations in science in his day and age.

Two persons occupy key positions in this passage. The first, according to al-Hajarī, is a famous astronomer at the court of Paris, who tells him that he has empirically tested astrological hypotheses (ikhtiyārāt) but found them falsified by events that had taken place. The identity of this astronomer (or astrologer) has not been determined yet. Al-Hajarī himself speaks about his own experiences in this field (he saw himself as possessing magic powers) and tells us about his teacher, Aḥmad b. Qāsim al-Mașyūb. The latter, a wellknown astronomer, mathematician, expert in magic and probably some sort of court astrologer at the Sa did court, had, like al-Hajari himself, an Andalusian background. The historian al-Ifrānī tells us the following about him and his death. ${ }^{70}$ Sultan Zaydān used to consult the scholar about his future. Once he consulted al-Mașyūb about an ongoing military campaign and wished to know whether he would emerge victorious. Al-Mașyūb was afraid and refused to answer, but the sultan promised that his blood would not be spilled. He then told him that the defeat would be monstrous. The sultan, afraid that this might become public knowledge, had him poisoned, and in this way was able to maintain that he had not broken his oath: indeed, no blood had been spilled! This event is said to have occurred in 1613. Al-Hajarī, writing his account of it much later, describes how such astrological calculations were actually made by alMașyūb. He also tells how the scholar had calculated his lifespan, along with two astrologers the author had consulted in Seville. It is

${ }^{69}$ Al-Hajarī, Kitāb nāṣir al-dīn, 190-191.

70 Al-Ifrānī, Muḥammad, Kitāb ṣafwat man intashar min akhbār șulahāà al-qarn al-ḥādì 'ashar, Fez, s.a., 104. 
amusing that al-Hajarî's commentary concludes they had all been wrong, and that he had recently reached a much higher age than any of the scholars had calculated. I interpret al-Hajarî's words as expressing distrust in astrology, possibly inspired by his belief in the omnipotence of God to do as he wills, powers that he thinks cannot be influenced by astrological operations. What is important in this context, however, is not al-Hajarî's personal view, but that he seems to be aware of the discussions about the new empirical «method»: it is no longer sufficient if a theory is consistent in itself, the important question now is its value when tested in empirical reality. Whereas Aristotelian theory had been based on the idea that the sublunar world was transient and the cosmos immutable, in the new paradigm the cosmos was seen as a unity governed by universal laws. ${ }^{71}$ This assumption had an inbuilt tendency to make divine intervention in the world redundant, for what place would God occupy in a world governed by impersonal laws? The passage shows that the scientific changes touched the Moriscos, who were acting as mediators between two worlds and whose cultural and scholarly expertise was valued on both sides of the Mediterranean.

Future research should reveal what sort of interfaces between science, the study of languages and religion interested the Moriscos and Conversos as minority groups in both early modern Europe and the early modern Islamic world. In both these worlds there were groups who saw science, in a religious (magic) or an increasingly non-religious form, as a means of bridging opposition between exclusivist views, because different religious groups had a common interest in certain questions, for example interpreting the signs of the times, whether a new age was imminent, in what manner the deity would reveal himself to the world and the status of the revelatory text. ${ }^{72}$ Such traditionally religious questions were also the subject of the new empirical sciences, which were objects of study in both Europe and the early modern Islamic world. The precise role of Moriscos in these developments is by no means clear yet, but the intense curiosity about the study of Arabic can certainly not be detached from these larger questions about religion, physical science and the cosmos. Similar questions were posed both in Paris and in

${ }^{71}$ Al-Ifrānī, Kitāb șafiwat man intashar, 263.

72 Von Stuckrad, Western Esotericism, 88. 
Marrakesh and in both cities the courts played an important role. The most conspicuous differences between Marrakesh and Paris were probably the ways the authorities reacted. When al-Mașyūb's astrological findings were unfavourable to the sultan, he lost his life. Even though anecdotal, this story accords with Floris Cohen's findings about the factors that determined the success of the empirical physical sciences in a number of European countries in comparison with other parts of the world. They were most successful in those countries where important social groups supported their ideas, which - as the famous confrontation between Galileo Galilei (15641642) and the Vatican around 1614 shows - often met with staunch opposition from traditional Christian circles.

A final question: how does one explain that Moriscos in the Diaspora were involved in the physical sciences, whereas in the Iberian peninsula scientific manuscripts in Arabic circulated predominantly among Jewish minorities and not among Muslims? The answer might be that the interest in medicine, astronomy, geography, biology and natural philosophy, while not absent in the Iberian peninsula, was not reflected in the possession of Arabic and Aljamiado texts. Such Mudejars and Moriscos probably read and possessed Latin and Spanish texts. The possession of such texts among moriscos has not yet been studied systematically. Needless to say, such a study would not be easy, for the Mudejars and Moriscos in question probably differed very little from the old Christian Spanish population in respect of their literary and scholarly culture. But they, too, brought their learning with them to the other side of the Mediterranean during the expulsions, where it aroused the interest of the Moroccan authorities, especially in court circles. ${ }^{73}$

Recibido: 30/04/2010

Aceptado: 21/06/2010

\footnotetext{
${ }^{73}$ In this regard, also see García-Arenal, M., Ahmad al-Mansur. The beginnings of modern Morocco, Oxford, 2009, 34ff. In this highly interesting study she describes Ahmad al-Manșūr as a man who emerges from the European and Moroccan chronicles with an interest in knowledge and intellectual curiosity, who had received an extensive education in Islamic religious and secular sciences, and especially keen on mathematics and astrology.
} 